\title{
Sistem Pendukung Keputusan Penentuan Lokasi Pembangunan Peternakan Ayam Menggunakan Metode MOORA
}

\author{
Eka Larasati Amalia ${ }^{1}$, Agung Nugroho Pramudhita ${ }^{2}$, M Ridlwan Aditya ${ }^{3}$ \\ 1,2.,3 Teknik Informatika, Teknologi Informasi, Politeknik Negeri Malang \\ 1eka.larasati@polinema.ac.id, ${ }^{2}$ agungpramudhita@gmail.com, ${ }^{3}$ adtya1997@gmail.com
}

\begin{abstract}
Abstrak: Penelitian ini bertujuan untuk membantu para peternak pemula untuk menentukan lokasi pembangunan peternakan ayam menggunakan metode Moora. Faktor lokasi untuk menentukan peternakan ayam adalah salah satu faktor yang penting, karena bila lokasi peternakan dekat dengan jalan raya, maka ayam akan terkena kebisingan alat transportasi serta mudah stres, tetapi sebaliknya jika peternakan ayam dekat dengan tempat pemotongan atau penjualan seperti pasar, maka biaya transportasinya akan relatif lebih murah. Metode Moora mempunyai perhitungan matematis yang sederhana dan stabil. Metode MOORA memiliki hasil perhitungan matematis yang tepat dalam mengambil suatu keputusan. Metode MOORA memiliki keunggulan daripada metode-metode yang lain yaitu lebih sederhana dan mudah diimplementasikan. Tingkat pemilihan dalam metode MOORA yang cukup baik dapat memutuskan suatu solusi alternatif dalam suatu permasalahan. Penelitian ini direkomendasikan untuk para peternak pemula yang ingin memulai bisnisnya.
\end{abstract}

Kata kunci-komponen; peternakan; ayam;

\section{PENDAhuluan}

$\mathrm{D}$ i zaman yang semakin modern, penemuan-penemuan yang diciptakan oleh manusia untuk mempermudah manusia melakukan suatu pekerjaan dengan cara yang lebih praktis, maka banyak kasus-kasus dalam pekerjaan yang dihadapkan pada pembuatan dan pengambilan keputusan. Contohnya seperti pengambilan keputusan terhadap rencana kerja serta pembobotan kriteria. Pengambilan keputusan dari suatu permasalahan, baik yang sederhana maupun masalah relatif kompleks hingga masalah yang paling kompleks, tentunya dibutuhkan data berupa informasi-informasi yang berdasarkan fakta, pengolahan informasi secara mendetail, serta metode pengambilan keputusan apa yang tepat digunakan.

Lokasi juga merupakan sumber daya yang terbatas ketersediaannya, di dunia ini tidak ada suatu tempat yang memiliki kesamaan dengan tempat lainnya. Oleh karena itu keputusan untuk menentukan lokasi peternakan ayam harus diperhitungkan dengan sangat matang. Penentuan lokasi penting dilakukan karena usaha peternakan memerlukan suatu areal khusus karena sifat dan kondisi fisiologisnya. Besar atau kecilnya usaha peternakan ayam tetap membutuhkan suatu lokasi agar benar-benar membawa manfaat untuk peternak serta tidak merugikan pihak-pihak lainnya. Peternak ayam pemula biasanya telalu fokus pada beberapa hal teknis saja seperti perawatan ayam dan pakan ayam, tetapi untuk lokasi pembangunan peternakan ayam dikategorikan kedalam prioritas paling rendah. Seperti yang sering kita lihat, banyak lokasi peternakan ayam yang letaknya berdekatan dengan tempat tinggal pemiliknya, dengan alasan lebih mudah dalam pengontrolan ternak. Namun cara tersebut dipandang kurang tepat jika diterapkan pada peternakan ayam instensif.

Faktor lokasi adalah faktor yang paling penting, apabila faktor lokasi tidak diprioritaskan, hal tersebut juga bisa membuat kerugian lingkungan dan masyarakat seperti bau kotoran ayam yang berkaitan dengan unsur nitrogen dan sulfida, yang bisa tercium sampai pemukiman warga, dan juga banyaknya lalat yang masuk ke pemukiman warga. Lalat sendiri diketahui merupakan vektor dari berbagai penyakit, sehingga dapat menjadi satu ancaman yang perlu diperhatikan secara serius. Bukan hanya itu saja, terdapat faktor lain yang dapat mengganggu lingkungan sekitar, gangguan tersebut meliputi suara berisik ayam ternak, ayam berkeliaran masuk kedalam 
pemukiman warga, limbah pakan dan air buangan aktifitas peternakan, lalu lintas pengangkutan produksi dan sarana produksi, serta kontaminasi bakteri serta virus dari ayam-ayam ternak tersebut.

Suasana lingkungan peternakan ayam yang terlalu ramai bisa jadi membuat ayam-ayam ternak tidak nyaman hingga stres, sehingga hal tersebut dapat mengganggu produksi, namun hendaknya lokasi peternakan tetap memungkinkan adanya jalur transportasi dan komunikasi yang berguna untuk memudahkan pemasaran hasil ternak dan penyediaan faktor produksi. Faktor lain yang tidak kalah pentingnya ialah lokasi peternakan ayam dekat dengan sumber air bersih, sumber air bersih dapat berupa sumur ataupun sungai. Seperti halnya kehidupan sehari-hari, air menjadi kebutuhan utama dalam beternak baik untuk minum maupun untuk membersihkan kandang dan kebutuhan lainnya. Air yang bersih juga dapat menjamin kesehatan dan kebersihan dari peternakan ayam tersebut.

Dengan adanya permasalahan diatas, penulis mencoba merancang dan membangun sistem penentuan lokasi pembangunan peternakan ayam menggunakan metode MOORA. Penulis melakukan riset serta penelitian untuk sistem ini bertujuan untuk memberikan kontribusi dalam bidang peternakan, yaitu merekomendasikan beberapa lokasi lahan yang tepat bagi para peternak ayam untuk membangun peternakan ayamnya. Penentuan lokasi lahan peternakan ayam ini berdasarkan kriteria-kriteria yang didapatkan penulis dari observasi, wawancara dan kuisioner. Penelitian ini juga didukung beberapa rekomendasi dari penelitian-penelitian dengan tema geographic information system. Metode MOORA stabil, kuat serta membutuhkan perhitungan matematis yang sederhana. Selain itu juga metode ini juga memiliki hasil yang lebih akurat dan tepat sasaran dalam membantu pengambilan keputusan. Bila dibandingkan dengan metode yang lain metode MOORA lebih sederhana dan mudah diimplementasikan. Penggunaan metode MOORA memiliki tingkat selektifitas yang baik dalam menentukan suatu alternatif.

\section{LANDASAN TEORI}

\section{A. Sistem Pendukung Keputusan (SPK)}

Sistem Pendukung Keputusan (SPK) atau Decision Support System (DSS) ialah suatu sistem yang memiliki kemampuan untuk memecahkan masalah yang relatif kompleks dengan memberikan suatu solusi. Sistem Pendukung Keputusan ini dapat digunakan untuk membantu mengambil suatu keputusan (decision) berdasarkan seberapa penting dan tidaknya tingkatan kriteria atau kondisi yang diinputkan kedalam sistem.

\section{B. Geographic Information System (GIS)}

Geographic Information System (GIS) merupakan sistem yang digunakan untuk menampilkan dan menganalisis informasi-informasi tentang detail kondisi geografis permukaan bumi. GIS dapat diartikan sebagai suatu kesatuan komponen sistem yang bekerja sama membentuk dan menggabungkan seluruh informasi berbasis geografis(permukaan bumi).

\section{Rule-Based System}

Rule-Based system adalah sebuah aturan untuk memecahkan suatu masalah yang kompleks dengan aturan logika if-then. Metode ini berfungsi untuk mengelompokkan data-data yang sudah diolah dengan logika perhitungannya. Pola if-then ini mempermudah modifikasi atau perubahan data yang mendasar. Metode Rule-Based System juga diperlukan untuk menjelaskan tentang bagaimana mendapatkan suatu solusi.

\section{MOORA}

Metode Multi-Objective Optimization by Ratio Analysis (MOORA) ialah metode yang dicetuskan oleh Brauers dan Zavadkas pada tahun 2006. MOORA digunakan untuk mengambil keputusan suatu masalah berdasarkan beberapa kriteria. Sifat MOORA yang mudah dan fleksibel untuk dipahami dan diterapkan dalam proses seleksi bobot masing-masing kriteria untuk mengambil suatu keputusan. Tingkat selektifitas dalam menentukan solusi alternatif pada MOORA cukup baik berdasarkan ketentuan kriteria dari yang sangat penting sampai yang kurang penting. Oleh karena itu MOORA banyak digunakan dalam beberapa bidang ilmu pengetahuan. 
Langkah-langkah untuk penyelesaian masalah menggunakan metode Multi Objective Optimization On The Basis Of Ratio Analysis (MOORA) adalah sebagai berikut :

a. Menginputkan Nilai Kriteria

b. Membuat Matriks

$$
\mathrm{X}=\left[\begin{array}{cccc}
x_{11} & x_{12} & \ldots & x_{1 n} \\
x_{21} & x_{22} & \ldots & x_{2 n} \\
\ldots & \ldots & \ldots & \ldots \\
x_{m 1} & x_{m 2} & \ldots & x_{m n}
\end{array}\right]
$$

Semua atribut yang telah diidentifikasi dibentuk dalam matriks keputusan.

c. Matriks Normalisasi

d. Menghitung Nilai Optimasi

$$
y_{i}=\sum_{j=1}^{g} w_{j} x_{i j}^{*}-\sum_{j=g+1}^{n} w_{j} x_{i j}^{*}
$$

e. Perangkingan

Nilai $y_{i}$ dapat menjadi positif tergantung dari total maksimal (atribut yang menguntungkan) dalam matriks keputusan. Keyhole Markup Language (KML)

\section{E. $K M L$}

Keyhole Markup Language (KML) ialah bahasa markup yang berbasis XML, dibuat untuk menampilkan detail keterangan dan menampakan real situation pada peta online dua dimensi dan tiga dimensi (seperti Google Earth). Keyhole Markup Language (KML) telah menjadi standar resmi di Open Geospatial Consortium, yang merupakan himpunan industri internasional yang berpartisipasi mengembangkan standar-standar layanan berbasis lokasi pada publik.

\section{F. Google Maps API}

Google Maps ialah layanan pemetaan lokasi yang dikembangkan oleh Google, banyak yang menyebutnya sebagai peta online. Google Maps menampilkan peta jalan, kondisi lalu lintas, dan perencanaan rute untuk bepergian dengan berbagai pilihan seperti berjalan kaki, mobil, sepeda atau angkutan umum menggunakan citra satelit. Google Maps API merupakan sekumpulan komponen yang melakukan berbagai fungsi berkaitan dengan aplikasi pemetaan lokasi. Google Maps API dibuat dengan Javascript, sehingga API lebih mudah dipelajari bagi yang sudah mengenal Javascript atau pemrograman berbasis objek.

\section{METODE PENELITIAN}

Dalam merancang sistem penentuan pembangunan peternakan ayam ini menggunakan konsep dan alur dari Model Waterfal dan akan di jabarkan setiap poin sesuai dengan pekerjaan yang harus dikerjakan saat pembuatan sistem ini.

Tempat Penelitian : Kecamatan Purwodadi, Kabupaten Pasuruan, Jawa Timur. Waktu Penelitian : Januari-Juni 2019

\section{A. Analisis Kebutuhan}

Dalam analisis kebutuhan sistem, teknik pengumpulan data didapatkan melalui metode observasi. Observasi adalah teknik pengumpulan data yang tidak hanya mengukur sikap dari responden (wawancara atau angket) namun juga dapat digunakan untuk medapatkan berbagai fenomena yang terjadi. Teknik ini dapat digunakan apabila penelitian ditujukan untuk mempelajari perilaku manusia dan dilakukan pada responden yang tidak terlalu besar. Selain itu, observasi ini dilakukan dengan mengamati langsung tempat-tempat yang akan dijadikan untuk rekomendasi pembangunan peternakan ayam. Selain itu, penulis juga melakukan wawancara dan kuisioner kepada para petenak di Kecamatan Purwodadi. Teknik analisis data yang dilakukan 
melalui tahap pemeriksaan kelengkapan data, memeriksa kualitas data, menentukan kualitas pengukuran(analisis kuantitatif), melakukan grouping data, setelahnya baru dilakukan analisis perhitungan bobot masing-masing kriteria. Lalu yang terakhir adalah teknik pengujian, teknik pengujian yang digunakan adalah grey box testing. Grey Box Testing adalah metode pengujian fungsional yang dilakukan untuk menguji interaksi antara pengguna dengan sistem, sehingga ketika penulis melakukan pengujian dari penelitian ini, hasil pengujian yang diharapkan yaitu ketepatan penentuan lokasi berdasarkan kriteria-kriteria pendukung yang telah ditentukan. Penulis juga melakukan teknik pengujian berupa demo sistem kepada para peternak secara langsung.

\section{B. Desain Sistem}

Desain Sistem membantu dalam menentukan perangkat keras(hardware) dan sistem persyaratan juga membantu dalam mendefinisikan arsitektur sistem secara keseluruhan. Desain sistem tersebut meliputi Usecase Diagram, ER Diagram, dan FlowChart

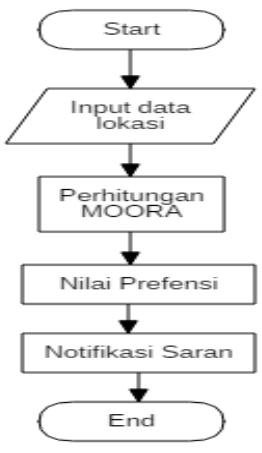

\section{Gambar 2. Flowchart sistem}

Alur dari flowchart diatas adalah sebagai berikut :

1. Pertama akan dilakukan penginputan lokasi yang diinginkan, data tersebut merupakan data kriteria penilaian dari sistem ini

2. Setelah semua data yang dibutuhkan terinput, maka secara otomatis sistem akan melakukan perhitungan dengan rumus yang sudah ditentukan metode MOORA untuk perhitungan skala prioritas.

3. Hasil dari perhitungan akan secara otomatis melakukan perangkingan prioritas lokasi pembangunan peternakan ayam.

4. Notifikasi saran lokasi terdekat apabila hasil dari perangkingan tidak valid.

Di dalam flowchart sistem terdapat flowchart metode MOORA untuk perhitungan prioritas dari masing-masing kriteria yang ada. 


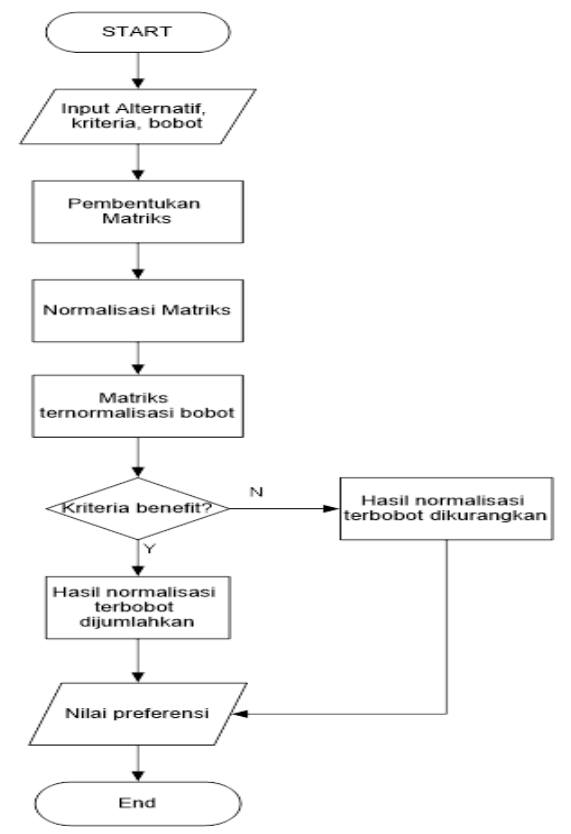

Gambar 3. Flowchart metode MOORA

Penjelasan dari flowchart metode MOORA dari sistem penentuan lokasi pembangunan peternakan ayam dimulai dari melakukan input data alternative, kriteria dan bobot. Data tersebut akan diproses untuk pembentukan matriks dan normalisasi matriks. Setelah itu akan ditentukan apakah kriteria akan benefit, kalau tidak maka hasil normalisasi akan dilakukan pengurangan. Apabila iya, maka hasil normalisasi terbobot dijumlahkan. Setelah itu akan mengeluarkan output berupa nilai preferensi.

\section{HASIL DAN PEMBAHASAN}

C. Pembahasan metode

Berikut ini adalah tabel kriteria yang dijadikan acuan oleh peneliti untuk Sistem Pendukung Keputusan Penentuan Lokasi Pembangunan Peternakan Ayam yang diperoleh dengan cara wawancara dengan peternak ayam dan camat di Kecamatan Purwodadi Kabupate Pasuruan.

TABEL 1 KRITERIA

\begin{tabular}{|c|c|c|c|}
\hline Kriteria & Keterangan & Bobot & Jenis \\
\hline C1 & $\begin{array}{c}\text { Kedekatan Lahan dengan } \\
\text { Pemukiman }\end{array}$ & 0.27 & Benefit \\
\hline C2 & Luas Lahan & 0.24 & Benefit \\
\hline C3 & $\begin{array}{c}\text { Tempat pemotongan atau } \\
\text { tempat penjualan ayam }\end{array}$ & 0.19 & Cost \\
\hline C4 & Akses Transportasi & 0.16 & Benefit \\
\hline C5 & Sumber air & 0.14 & Cost \\
\hline Total & & 1 & \\
\hline
\end{tabular}

Tabel 1 menginputkan kriteria-kriteria yang digunakan untuk perhitungan menggunakan metode MOORA. Kriteria pada perhitungan ini berfungsi untuk mengukur rekomendasi tempat pembangunan peternakan ayam, masing-masing dari kriteria tersebut harus memiliki bobot dari yang terpenting, sampai yang tidak terlalu penting dan juga menentukan apakah kriteria tersebut benefit atau cost. . Tiap urutan kriteria seperti C1,C2,C3,C4 dan C5 memiliki besaran bobotnya masing-masing. Penulis menentukan besaran bobot tersebut dari data-data yang telah dikumpulkan dan diolah sedemikian rupa. Benefit ialah manfaat atau keuntungan yang akan didapatkan, sedangkan cost adalah besaran tarif atau harga yang perlu dikeluarkan. 
TABEL 2 ALTERNATIF

\begin{tabular}{|c|c|c|c|c|c|}
\hline Alternatif & $\mathrm{C} 1$ & $\mathrm{C} 2$ & $\mathrm{C} 3$ & $\mathrm{C} 4$ & $\mathrm{C} 5$ \\
\hline pare rejo 1 & 0.25 & 0.75 & 0.25 & 0.5 & 1 \\
\hline Jatisari & 0.5 & 0.5 & 1 & 0.5 & 1 \\
\hline Pare rejo 3 & 0.5 & 0.25 & 1 & 0.5 & 0.75 \\
\hline Cowek & 0.75 & 0.25 & 1 & 0.5 & 0.5 \\
\hline Capang 1 & 0.5 & 0.25 & 1 & 1 & 0.5 \\
\hline Pucang sari & 0.75 & 0.25 & 0.75 & 1 & 1 \\
\hline Gajah Rejo & 0.5 & 0.25 & 1 & 0.5 & 0.5 \\
\hline Gajah rejo 2 & 1 & 0.25 & 1 & 0.5 & 0.75 \\
\hline Pangkat & 3.1875 & 0.6875 & 6.625 & 3.3125 & 3.9375 \\
\hline Akar & 1.785357 & 0.829156 & 2.573908 & 1.820027 & 1.984313 \\
\hline
\end{tabular}

Tabel 2 berisikan delapan alternatif lokasi untuk pembangunan peternakan ayam, dan semua alternatif sudah diberi nilai dari masing-masing kriteria $\mathrm{C} 1, \mathrm{C} 2, \mathrm{C} 3, \mathrm{C} 4$, dan $\mathrm{C} 5$. Untuk memberi nilai pada masing-masing alternatif dibutuhkan kondisi, disini setiap kriteria mempunyai dua atau lebih kondisi seperti jarak antara lokasi pembangunan dengan pemukian, dan akses transportasi untuk menuju lokasi tersebut.

TABEL 3 NORMALISASI

\begin{tabular}{|c|c|c|c|c|c|}
\hline Alternatif & $\mathbf{C 1}$ & $\mathbf{C 2}$ & $\mathbf{C 3}$ & $\mathbf{C 4}$ & C5 \\
\hline A1 & 0.084215192 & 0.268328157 & 0.06509446 & 0.160128154 & 0.311399578 \\
\hline A2 & 0.168430384 & 0.178885438 & 0.26037782 & 0.160128154 & 0.311399578 \\
\hline A3 & 0.168430384 & 0.089442719 & 0.26037782 & 0.160128154 & 0.233549683 \\
\hline A4 & 0.252645576 & 0.089442719 & 0.26037782 & 0.160128154 & 0.155699789 \\
\hline A5 & 0.168430384 & 0.089442719 & 0.26037782 & 0.320256308 & 0.155699789 \\
\hline A6 & 0.252645576 & 0.089442719 & 0.19528337 & 0.320256308 & 0.311399578 \\
\hline A7 & 0.168430384 & 0.089442719 & 0.26037782 & 0.160128154 & 0.155699789 \\
\hline A8 & 0.336860768 & 0.089442719 & 0.26037782 & 0.160128154 & 0.233549683 \\
\hline
\end{tabular}

Pada tabel 3 setiap alternatif satu sampai ke delapan diganti dengan bilangan A1-A8 untuk memudahkan perhitungan, disini masing-masing nilai kondisi pada alternatif akan dibagi dengan hasil akar dari masing-masing kondisi yang dimiliki alternative A1-A8.

TABEL 4 NORMALISASI BOBOT

\begin{tabular}{|c|c|c|c|c|c|}
\hline Alternatif & C1 & C2 & C3 & C4 & C5 \\
\hline $\mathbf{A 1}$ & 0.022738102 & 0.064398758 & 0.01236795 & 0.025620505 & 0.043595941 \\
\hline $\mathbf{A 2}$ & 0.045476204 & 0.042932505 & 0.04947179 & 0.025620505 & 0.043595941 \\
\hline $\mathbf{A 3}$ & 0.045476204 & 0.021466253 & 0.04947179 & 0.025620505 & 0.032696956 \\
\hline $\mathbf{A 4}$ & 0.068214306 & 0.021466253 & 0.04947179 & 0.025620505 & 0.02179797 \\
\hline $\mathbf{A 5}$ & 0.045476204 & 0.021466253 & 0.04947179 & 0.051241009 & 0.02179797 \\
\hline $\mathbf{A 6}$ & 0.068214306 & 0.021466253 & 0.03710384 & 0.051241009 & 0.043595941 \\
\hline $\mathbf{A 7}$ & 0.045476204 & 0.021466253 & 0.04947179 & 0.025620505 & 0.02179797 \\
\hline $\mathbf{A 8}$ & 0.090952407 & 0.021466253 & 0.04947179 & 0.025620505 & 0.032696956 \\
\hline
\end{tabular}

Pada tabel 4 memuat perhitungan normalisasi bobot. Untuk mencari nilai normalisasi bobot dibutuhkan hasil dari normalisasi di atas, dan setelah itu dikalikan dengan bobot yang telah disetting atau diatur pada masing-masing kriteria yang ada. 
TABEL 5 NILAI PREFERENSI

\begin{tabular}{|c|c|c|c|c|}
\hline Alternatif & $\begin{array}{c}\text { Max } \\
(\mathbf{C 1 + C 2 + C 4})\end{array}$ & Min(C3+C5) & $\begin{array}{c}\text { Yi=Max- } \\
\text { Min }\end{array}$ & Ranking \\
\hline A1 & 0.112757364 & 0.055963887 & 0.05679348 & 2 \\
\hline A2 & 0.114029214 & 0.093067727 & 0.02096149 & 7 \\
\hline A3 & 0.092562961 & 0.082168742 & 0.01039422 & 8 \\
\hline A4 & 0.115301063 & 0.071269757 & 0.04403131 & 5 \\
\hline A5 & 0.118183466 & 0.071269757 & 0.04691371 & 4 \\
\hline A6 & 0.140921567 & 0.080699781 & 0.06022179 & 1 \\
\hline A7 & 0.092562961 & 0.071269757 & 0.0212932 & 6 \\
\hline A8 & 0.138039165 & 0.082168742 & 0.05587042 & 3 \\
\hline
\end{tabular}

Pada tabel 5 adalah proses terakhir dari perhitungan metode MOORA, disini Hasil dari normalisasi bobot pada tiap kondisi yang dimiliki alternatif dibagi menjadi 2 (Benefit dan Cost) untuk kriteria benefit dijumlahkan dengan kriteria yang benefit juga $(\mathrm{C} 1+\mathrm{C} 2+\mathrm{C} 4)$ dan untuk kriteria yang cost akan dijumlahkan dengan kriteria yang cost juga $(\mathrm{C} 3+\mathrm{C} 5)$. Setelah itu hasil dari penjumlahn tersebut akan di kurangi (hasil kriteria benefit - hasil kriteria cost) dan akan di rangkingkan menurut yang terbesar.

\section{KESIMPULAN DAN SARAN}

\section{A. Kesimpulan}

Dari penelitian yang sudah dilakukan, maka dapat ditarik kesimpulan sebagai berikut:

- Sistem pendukung keputusan penentuan lokasi pembangunan peternakan ayam mengunakan metode MOORA ini dapat digunakan untuk membantu pengambilan suatu keputusan dalam pemilihan lokasi yang menguntungkan untuk pembangunan peternakan ayam dan juga agar mengurangi dampak buruk dari pembangunan peternakan tersebut. Hasil dari rekomendasi tempat selalu ditampilkan dan dihitung dengan masing-masing kriteria yang ada serta menghasilkan perangkingan dari masing-masing alternatif.

- Sistem pendukung keputusan penentuan lokasi pembangunan peternakan ayam ini dibuat berbasis web, sehingga dapat diakses dimana saja menggunakan jaringan internet.

- Penelitian ini dapat memberikan solusi dan rekomendasi bagi para peternak yang ingin memulai bisnisnya dilahan yang baru. Sistem tersebut menampilkan dan memaparkan secara detail lokasi-lokasi lahan yang direkomendasikan kepada para petenak berdasarkan perhitungan dan pembobotan kriteria-kriteria. Dan juga, sistem ini menawarkan beberapa solusi alternatif rekomendasi lahan pembangunan peternakan ayam di Kecamatan Purwodadi.

\section{B. Saran}

Berdasarkan penelitian ini, saran yang diberikan untuk pengembangan sistem ini, yaitu:

1. Sistem pendukung keputusan ini mampu digunakan untuk menyelesaikan permasalahan yang lain dengan menggunakan metode penghitungan yang lebih baik lagi dan diharapkan dapat memberikan solusi yang terbaik.

2. Parameter yang digunakan untuk pemilihan lokasi pada sistem bisa menggunakan parameter selain yang digunakan pada sistem ini. 


\section{DAFTAR PUSTAKA}

[1] Ardi Kusuma, Amatillah Nasution, Reka Safarti, Rivalri Kristianto Hondro dan Efori Buulolo. "Sistem Pendukung Keputusan Pemilihan Siswa/I Teladan Dengan Menggunakan Metode Multi-Objective Optimization on The Basis of Ratio Analisis (MOORA), Volume 5, No. 2, April 2018.

[2] Aprillya Ulva, Dani Iqbal, Nuraini, Mesran, Dian U Sutiksno, Yuhandri 2018. Sistem Pendukung Keputusan Pemilihan Bibit Lele Terbaik Menggunakan Metode MOORA (MultiObjective Optimization On The Basis Of Ratio Analysis) dan WASPAS (Weight Aggregated Sum Product Assesment)

[3] David.2016. Sistem Informasi Geografis Pemetaan Lokasi Ideal Taman Nasional di Wilayah Kalimantan Barat

[4] Budhi Gustiandi, 2011. Rancang Bangun Sistem Penampilan Dinamika Titik Panas di Indonesia Berbasis Keyhole Markup Language (KML) Dinamis. Peneliti Bidang Teknologi Akuisisi dan Stasiun Bumi, LAPAN

[5] ManiaCMS, (06 Mei 2015), "Pengertian Xampp", [online], 2012, Available : http://www.maniacms.web.id/2012/01/pengertian-Xampp.html

[6] Basuki, AP, 2010, Membangun Web Berbasis PHP dengan Framework Codeigniter, Lokomedia, Yogyakarta.

[7] Ihsan Atkia, (06 Mei 2015), "Fitur Sublime Text", [online], 2014, Available : http://ihsanatkia.com/featur-lebih-dari-package-sublime-text/

[8] Abdul Kadir (2013). Pengertian MySQL. Tersedia dalam : Buku Pintar Programer Pemula PHP. Yogyakarta. Mediakom.

[9] Sudrajat , Agus Yuniawan Isyanto, 2018. Faktor-Faktor Yang Berpengaruh Terhadap Pendapatan Usaha Ternak Ayam Sentul Di Kabupaten Ciamis

[10] Sri Wardani, Iin Parlina, Ahmad Revi. Analisis Perhitungan Metode Moora Dalam Pemilihan Supplier Bahan Bangunan Di Toko Megah Gracindo Jaya

[11] Revan Asyari Sabir, Dian Novian, Abd. Aziz Bouty. 2015. Penerapan Metode AHP dalam Menentukan Kawasan Peternakan

[12] Peraturan Menteri Pertanian Republik Indonesia Nomor 31/Permentan/Ot.140/2/2014 